\title{
Relations Among Land Cover, Streamflow, and Water Quality in the North Canadian River Basin near Oklahoma City, Oklahoma, 1968-2009
}

\section{Introduction}

The U.S. Geological Survey, in cooperation with the city of Oklahoma City, has collected water-quality samples at the North Canadian River near Harrah, Oklahoma (the Harrah station), since 1968, and the North Canadian River at Britton Road at Oklahoma City, Oklahoma (the Britton Road station), since 1988 (fig. 1). The North Canadian municipal wastewatertreatment plant, managed by the city of Oklahoma City, is the largest wastewater-treatment plant in the North Canadian River Basin and discharges effluent between the Britton Road and Harrah stations. Water-quality constituent concentrations were summarized, and trends in concentrations and frequencies of detection of selected constituents with time were evaluated to determine if changes in land cover, streamflow, and other potential sources of constituents in water had significant effects on water quality in the North Canadian River downstream from Oklahoma City.

\section{Changes in Land Cover and Streamflow with Time}

Predominant land-cover changes between 1992 and 2001 in the basin between the Harrah station and Lake Overholser upstream were an increase in developed/barren land cover and a decrease in pasture/hay land cover (figs. 1, 2). Increases in developed land can increase concentrations of nitrogen, phosphorus, and related manmade chemicals, such as pesticides and volatile organic compounds, in rivers and associated streambed sediments and fish tissues (Gilliom and others, 2007; Dubrovsky and others, 2010). Streamflow at the time of sampling also can affect water-quality data. Streamflow during base-flow (low-flow) conditions is composed largely of groundwater seepage and discharge from point sources, whereas, streamflow during runoff (high-flow) conditions is composed largely of rainfall runoff from the land surface of a basin. There were no notable trends with time in median and higher streamflow at either station (fig. 3). There were

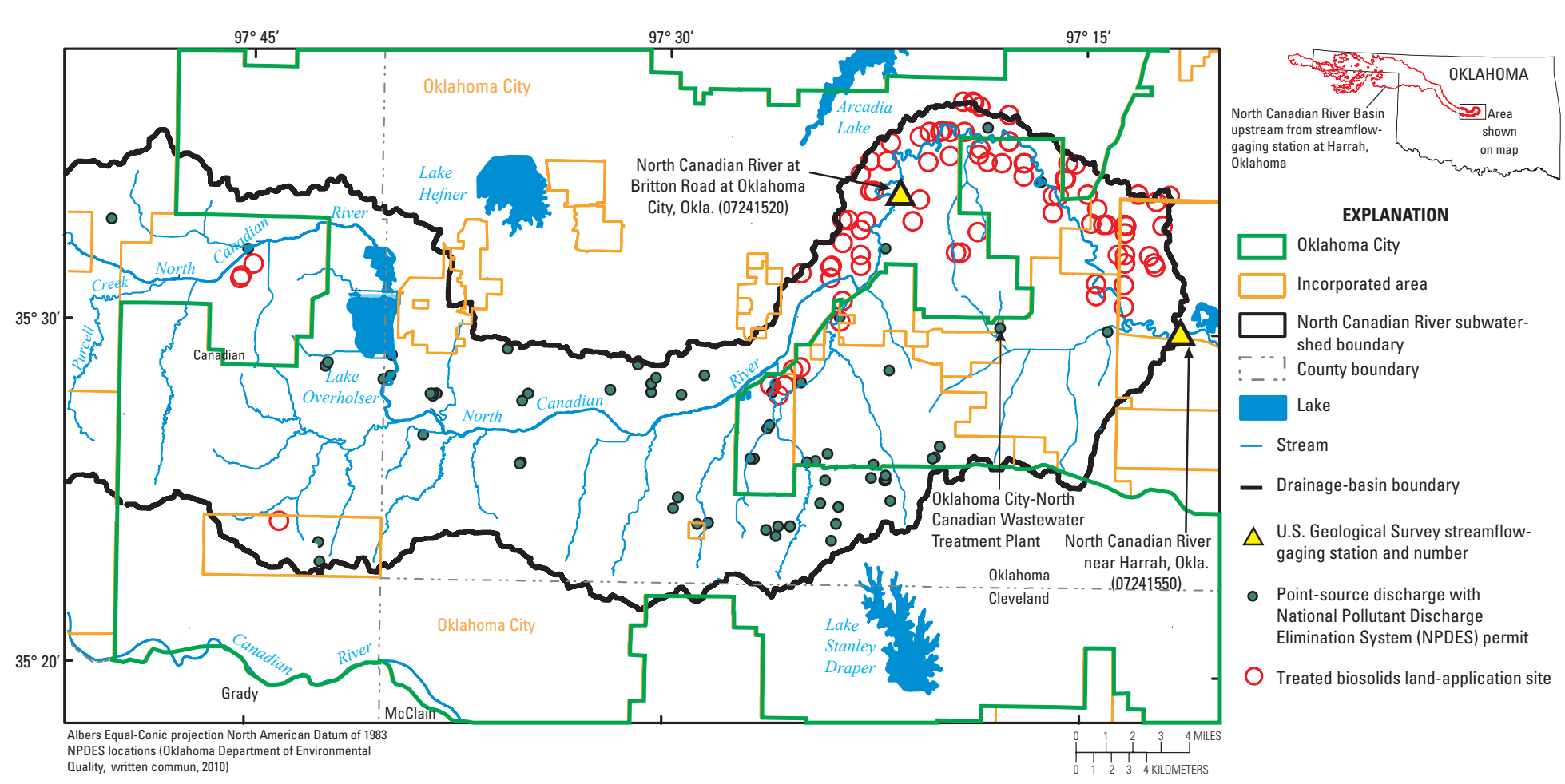

Figure 1. Locations of two sampled streamflow-gaging stations, point-source discharges, and treated biosolids land-application sites in the North Canadian River Basin near Oklahoma City, Oklahoma. 


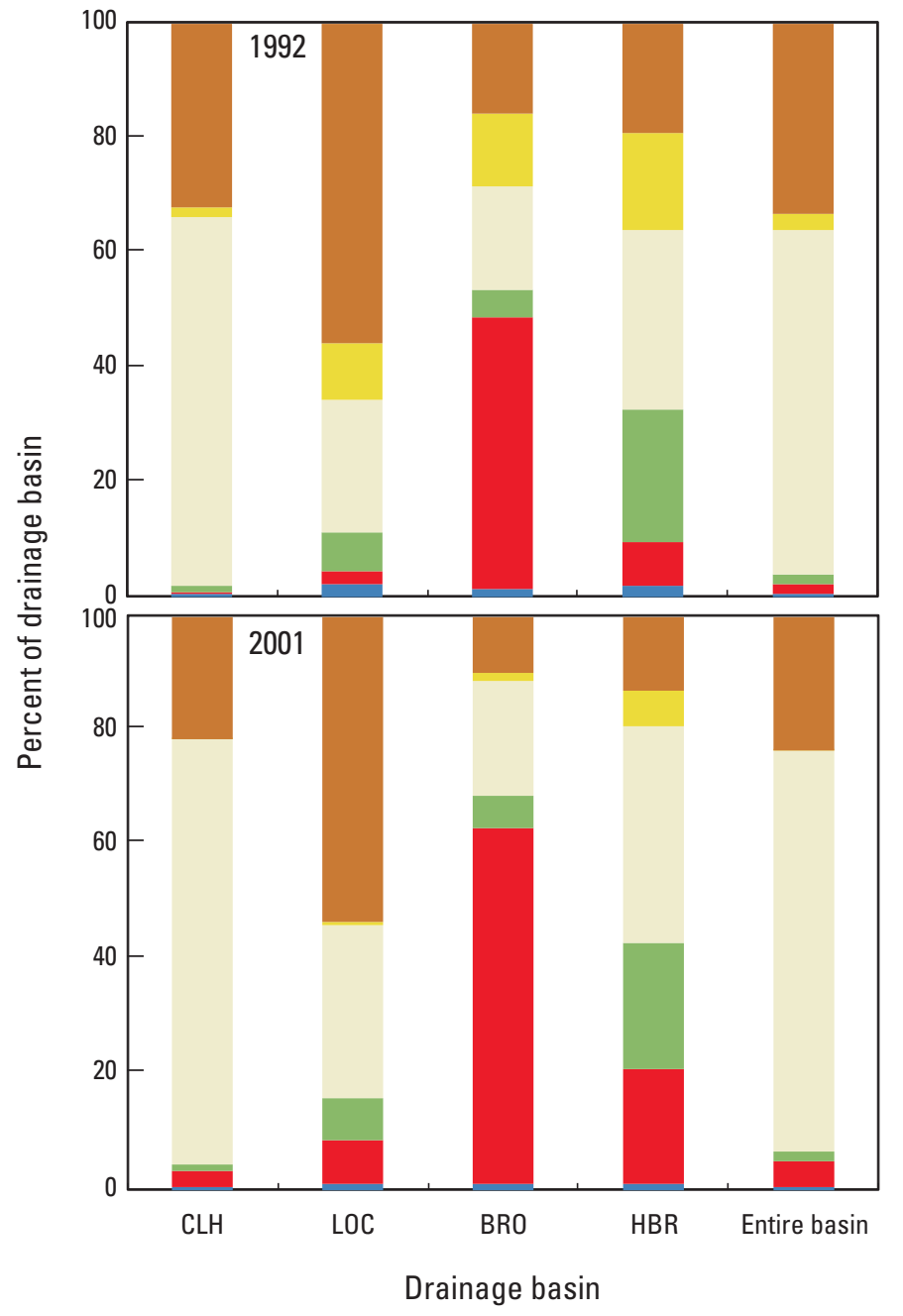

EXPLANATION

Water/Wetland
Developed/Barren
Forest
Grassland/Scrub
Pasture/Hay
Cropland

CLH-Canton Lake Dam to Headwaters

LOC-Lake Overholser Dam to Canton Lake Dam

BR0-Streamflow-gaging station at North Canadian River at Britton Road at Oklahoma City (07241520) to Overholser Dam

HBR-Streamflow-gaging station at North Canadian River near Harrah (07241550) to streamflow-gaging station at Britton Road at Oklahoma City (07241520)

Land-cover areas from National Land-Cover Datasets (U.S. Geological Survey, 2002; Homer and others, 2004)

Figure 2. Percentages of land-cover for six reclassified land-cover categories from the 1992 and 2001 National Land Cover Dataset in four subbasins of the North Canadian River Basin upstream from the North Canadian River near Harrah, Oklahoma, streamflow-gaging station.

significant downward trends in streamflow characteristics that represented lower streamflow at both stations ( $p$-value of Kendall tau test less than or equal to 0.05 (Kendall and Gibbons, 1990)). There were no significant trends in precipitation-adjusted annual streamflow at either station.

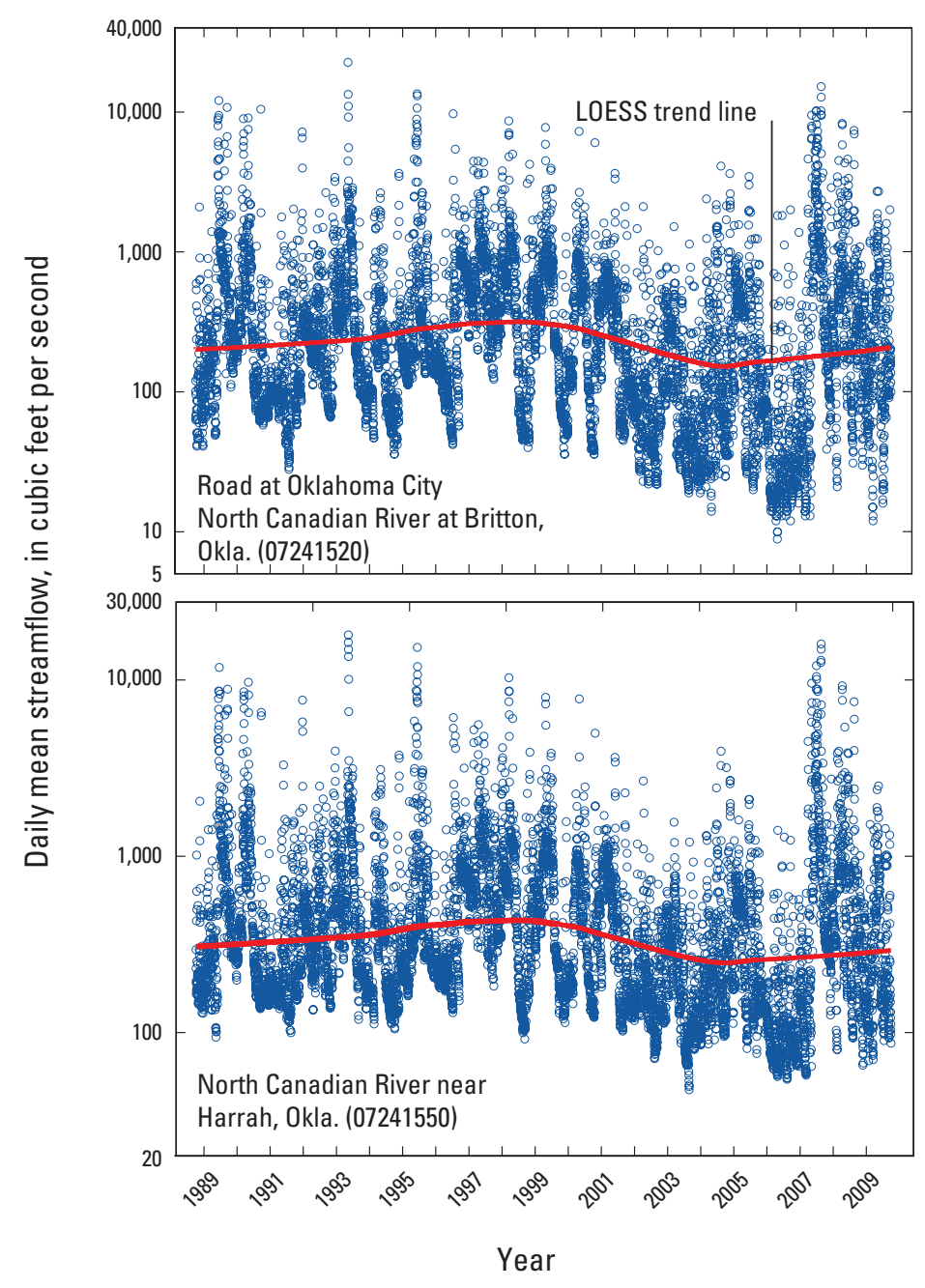

Figure 3. Daily mean streamflow at the North Canadian River at Britton Road at Oklahoma City, Oklahoma, and the North Canadian River near Harrah, Okla., streamflow-gaging stations, 1988-2009.

\section{Water-Quality Comparisons}

Statistical summaries, frequencies of detection, and percentages of samples with concentrations exceeding Criterion Continuous Concentrations (established to protect fish and other aquatic life, U.S. Environmental Protection Agency, 2010) were calculated for 157 water-quality constituents for both streamflowgaging stations. Concentrations of dissolved chloride, lead, cadmium, and chlordane most frequently exceeded the Criterion Continuous Concentration in water-quality samples collected at both stations. Water samples collected at the Harrah station had more frequently (greater than 10 percent) detected pesticides than water samples collected at the Britton Road Station from 1988 to 2009.

Dissolved nitrogen and phosphorus concentrations, which can affect growth of aquatic plants, dissolved oxygen concentrations in water, and fish habitat, were significantly greater in water samples collected at the Harrah station than at the Britton Road station ( $\mathrm{p}$-values of the Wilcoxon rank-sum test less than or equal to 0.05 (Wilcoxon, 1945)), whereas, specific conductance, an indicator of total dissolved solids commonly associated with groundwater, was greater at the Britton Road station (fig. 4). Dissolved oxygen concentrations indicate suitability of water for 

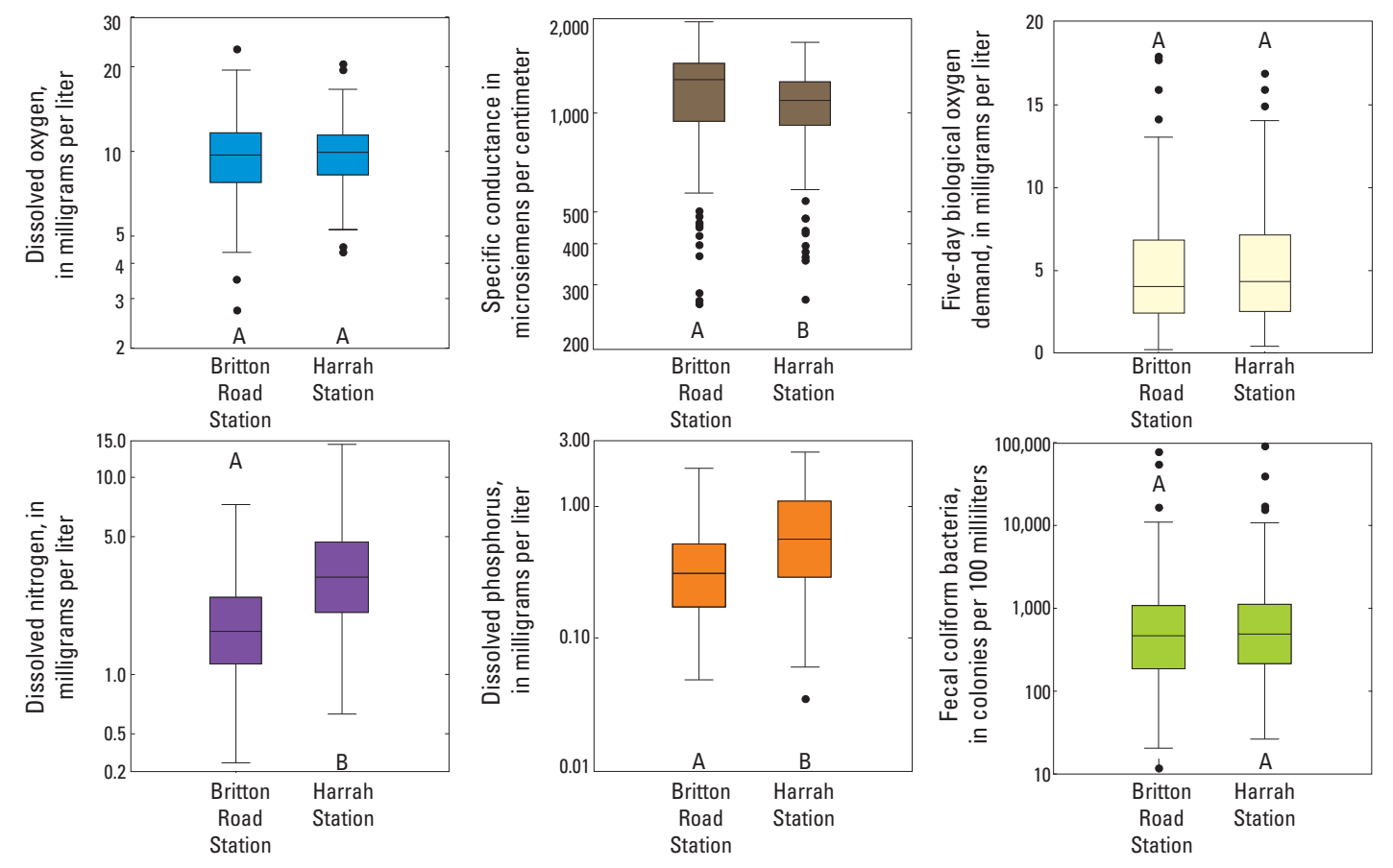

EXPLANATION

A Daily constituent distributions with the same letter are not significantly different ( $p$ less than or equal 0.05 of the Wilcoxon signed-rank test)

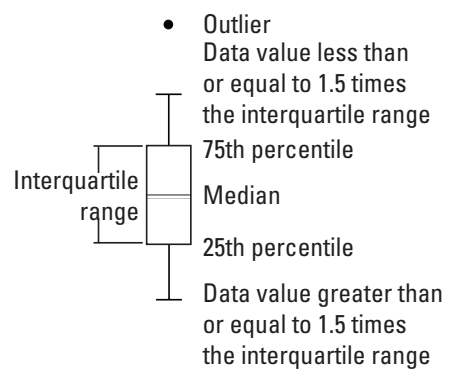

Figure 4. Distribution of concentrations of selected constituents in water samples collected at the North Canadian River at Britton Road at Oklahoma City, Oklahoma, and the North Canadian River near Harrah, Okla., streamflow-gaging stations, $1988-2009$.

oxygen-breathing aquatic organisms such as fish and amphibians. Biochemical oxygen demand indicates the propensity of chemicals and microorganisms in water to consume dissolved oxygen. Fecal coliform bacteria indicate contamination of water by feces from humans, livestock, and wildlife. Concentrations of dissolved oxygen, biochemical oxygen demand, and fecal coliform bacteria were not significantly different between the Britton Road and Harrah stations. Water temperatures also can affect the suitability of water for aquatic animals, many of which are temperaturesensitive and require greater concentrations of dissolved oxygen associated with lower water temperatures. Daily minimums and maximums and diurnal fluctuations of water temperature were significantly greater at the Harrah station than at the Britton Road station. Daily maximum and diurnal range of dissolved oxygen concentrations were significantly greater at the Britton Road station than at the Harrah station.

\section{Water-Quality Trends with Time}

Based on p-values of the non-parametric Kendall tau test (Kendall and Gibbons, 1990) of less than or equal to 0.05, daily and monthly mean water temperature increased with time. Daily and monthly mean specific conductance at the two stations decreased with time. There were small downward trends in daily mean dissolved oxygen in water samples collected at both stations and low daily mean dissolved oxygen concentrations (less than 2 milligrams per liter) were measured more frequently at both stations after 1999.

Slight decreases in fecal coliform bacteria concentrations occurred from 1988-2009 in water samples collected at the Britton Road station. There were no trends with time, however, in fecal streptococcal bacteria concentrations in water samples collected at either station. Chlorophyll $a$ concentrations, which commonly are used to estimate the amount of aquatic plant growth, did not change with time at the Harrah station in water samples collected after 1987.

From 1988-2009, there was a downward trend in flowadjusted dissolved phosphorus concentration ( $\mathrm{p}$-value less than or equal to 0.05 ) at the Britton Road station. Flow adjustment is a procedure used to normalize the concentration of a constituent to streamflow, which can change considerably over time. From 1988-98, there were no significant trends in unadjusted and flowadjusted dissolved oxygen concentration at either station, and there were significant downward trends in unadjusted and flow-adjusted nitrogen and phosphorus concentrations. From 1999-2009, there were significant downward trends in unadjusted dissolved oxygen concentrations at both stations. From 1999-2009, there were also significant downward trends in flow- and temperature-adjusted dissolved oxygen concentrations in water samples collected at the Harrah station, significant upward trends in flow-adjusted dissolved nitrogen concentrations in water samples collected at both stations, and significant upward trends in flow-adjusted dissolved phosphorus concentrations only at the Harrah station (fig. 5).

Decreases in dissolved oxygen concentrations that coincide with increases in nitrogen and phosphorus concentrations may indicate increased eutrophication (plant growth that affects aquatic habitat structure and reduces dissolved oxygen concentrations through aerobic decomposition of organic matter). In flowing streams, much of that increased growth can be in periphyton growing on solid substrates in a stream, rather than phytoplankton floating in the water, which may explain why chlorophyll- $a$ concentrations in the water column did not increase significantly at the Harrah station with increases in nitrogen and phosphorus concentrations.

Annual frequencies of detection of the pesticides 2, 4-dichlorophenoxyacetic acid and bromacil increased with time. Annual frequencies of detection of of atrazine, chlorpyrifos, diazinon, dichlorprop, and lindane decreased with time. Annual frequencies of detection of dieldrin, heptochlor epoxide, and simazine did not change with time. 

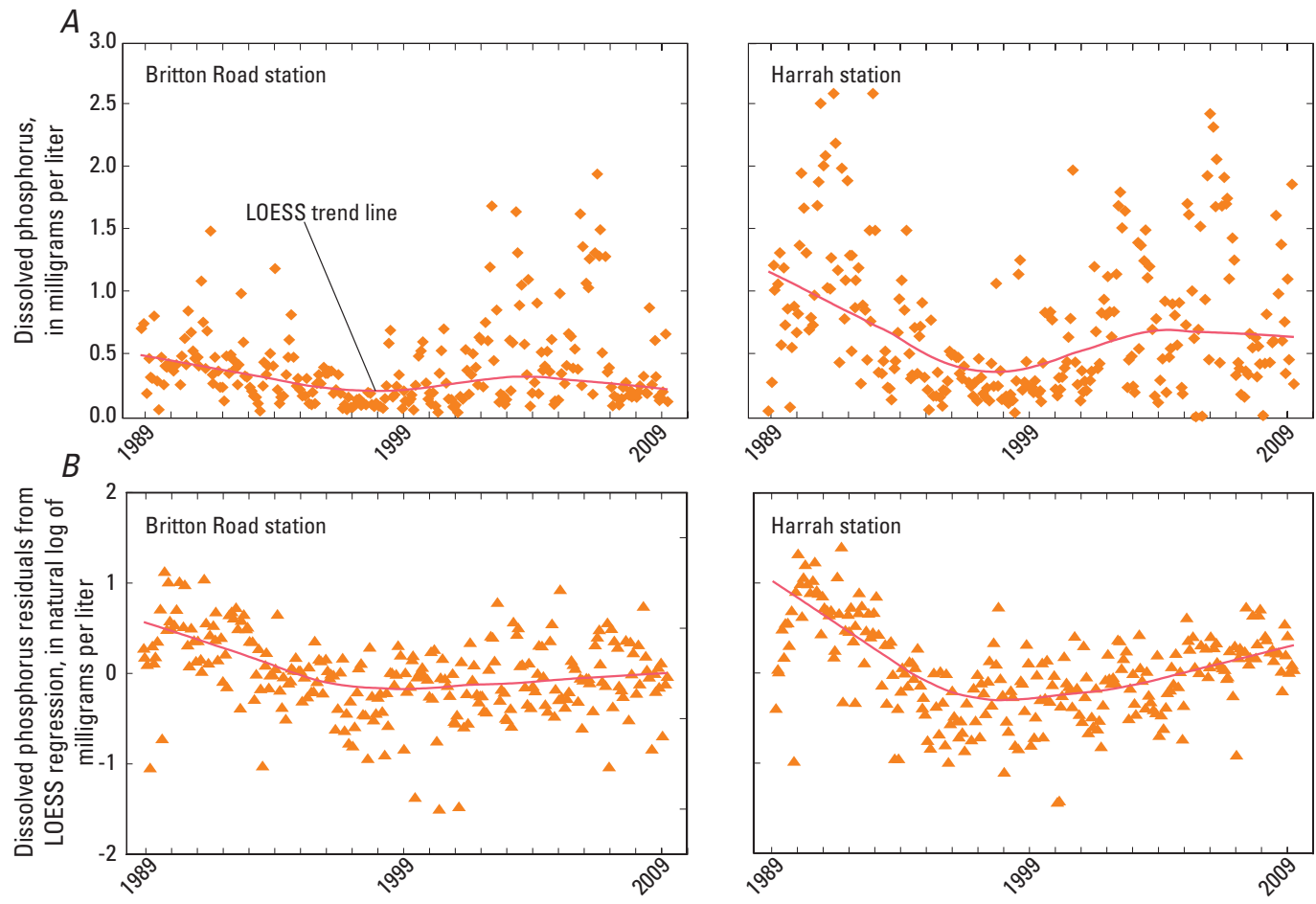

更

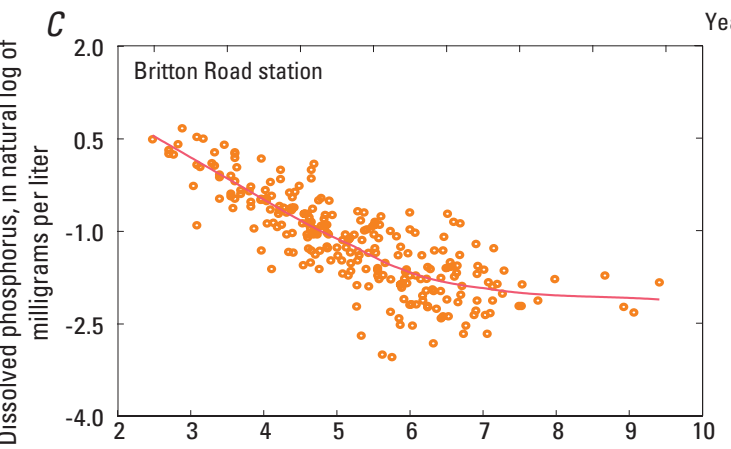

Yea

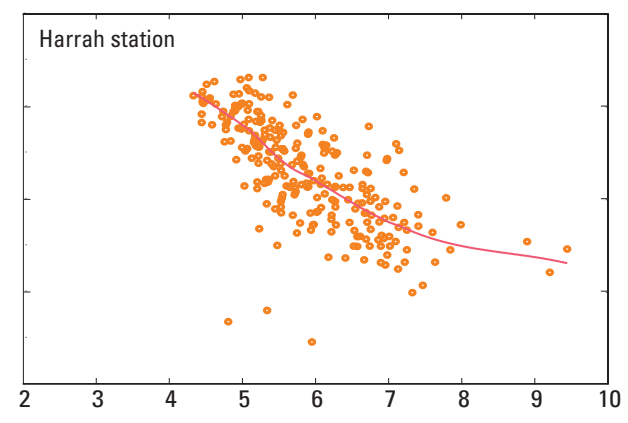

Natural log of streamflow, in cubic feet per second

Figure 5. Trends in dissolved phosphorus at the North Canadian River at Britton Road at Oklahoma City, Oklahoma, and the North Canadian River near Harrah, Okla., streamflow-gaging stations showing $A$., dissolved phosphorus with time; $B$., flow-adjusted dissolved phosphorus (error residuals) from a LOESS regression; and $C$., relation between dissolved phosphorus and streamflow.

\section{Conclusions}

Significant spatial differences and temporal trends in water quality may have been caused, in part, by increased urban development in the basins upstream from the Britton Road and Harrah stations. Decreasing dissolved oxygen concentrations coinciding with increasing nitrogen and phosphorus concentrations indicate that point and non-point sources of nitrogen and phosphorus compounds may be increasing eutrophication in the reach of the North Canadian River between those stations.

\section{References}

Dubrovsky, N.M., Burow, K.R., Clark, G.M., Gronberg, J.M., Hamilton P.A., Hitt, K.J., Mueller, D.K., Munn, M.D., Nolan, B.T., Puckett, L.J., Rupert, M.G., Short, T.M., Spahr, N.E., Sprague, L.A., and Wilber, W.G., 2010, The quality of our Nation's waters - Nutrients in the Nation's streams and groundwater, 1992-2004: U.S. Geological Survey Circular 1350, 174 p.
Esralew, R.A., Andrews, W.J., and Smith, S.J., 2011, Evaluation and trends of land cover, streamflow, and water quality in the North Canadian River near Oklahoma City, Oklahoma, 1968-2009: U.S. Geological Survey Scientific Investigations Report 2011-5117, $97 \mathrm{p}$.

Gilliom, R.J., Barbash, J.E., Crawford, C.G., Hamilton, P.A., Martin, J.D., Nakagaki, Naomi, Nowell, L.H., Scott, J.C., Stackelberg, P.E., Thelin, G.P., and Wolock, D.M., 2007, Pesticides in the Nation's streams and ground water 1992-2001: U.S. Geological Survey Circular 1291, 172 p.

Homer, C.C., Huang, Chengquan, Yang, Limin, Wylie, Bruce, and Coan, Michael, 2004, Development of a 2001 national landcover database for the United States: Photogrammetric Engineering and Remote Sensing, v. 70, no. 7, p. 829-840.

Kendall, M., and Gibbons, J.D., 1990, Rank correlation methods (5th ed.): New York, Oxford University Press, 260 p.

U.S. Environmental Protection Agency, 2010, National recommended water quality criteria: U.S. Environmental Protection Agency, accessed October 27, 2010, at http://water. epa.gov/scitech/swguidance/ waterquality/standards/current/ index.cfm.

U.S. Geological Survey, 2002, National Land Cover Dataset 1992 (NLCD): Earth Resources Observation and Science (EROS) Center, accessed May 26, 2011, at http://landcover.usgs.gov/natllandcover.

Wilcoxon, Frank, 1945, Individual comparisons by ranking methods: Biometrics Bulletin, v. 1, no. 6, p. 80-83.

\section{By Rachel A. Esralew, William J. Andrews, and S. Jerrod Smith}

\section{For more information, contact:}

Director

U.S. Geological Survey,

Oklahoma Water Science Center

202 NW 66th Street

Oklahoma City, OK 73116

405-810-4400

http://ok.water.usgs.gov 